\title{
Гипердопированный кремний для фотоэлектроники
}

\author{
Р.И. Баталов, Р.М. Баязитов \\ Казанский физико-технический институт, \\ Федеральный исследовательский центр «Казанский научный центр РАН», \\ Казань, 420029, ул. Сибирский тракт, 10/7 \\ тел:+7 (843) 231-9102, факс:+7 (843) 272-5075, эл.nочта: batalov@kfti.knc.ru
}

DOI 10.34077/RCSP2019-47

В последние 10 лет в мировой научной литературе бурное развитие получила тематика исследований, направленных на сильное легирование (свыше $10^{19} \mathrm{~cm}^{-3}$ ) монокристаллического кремния (гипердопирование) глубокоуровневыми примесями халькогенидов (сера, селен, теллур) и переходных металлов (титан, кобальт, никель, серебро, золото)[1-4]. Целью такого легирования является формирование в запрещенной зоне кремния примесных уровней или зон, способствующих поглощению фотонов с энергией, меньшей, чем ширина запрещенной зоны полупроводника $\left(\mathrm{E}_{\mathrm{g}}=1.1\right.$ эВ). Это позволяет расширить спектральный диапазон фоточувствительности кремниевых фотоприемников в ИК-область $(\lambda>1200$ нм), а также повысить КПД солнечных элементов за счет более эффективного поглощения ИК-излучения солнечного спектра. При этом концентрация легирующих примесей должна достигнуть величины, соответствующей Моттовскому переходу изолятор-металл $\left(N \sim 10^{20} \mathrm{~cm}^{-3}\right)$, при которой примесная зона сливается с зоной проводимости, а локализованные на глубоких уровнях электроны становятся свободными. При таких высоких уровнях легирования в ИК-спектрах поглощения $\mathrm{Si}(\lambda=1100-2000$ нм) наблюдается значительный рост поглощения (до 30 \%), повышение времени жизни носителей, инверсия типа проводимости в легированном слое (обычно $\mathrm{p} \rightarrow \mathrm{n}$ ) и значительное возрастание фототока в ИК-области. Поскольку глубокоуровневые примеси имеют низкую равновесную растворимость в кремнии (обычно не выше $\left.10^{17} \mathrm{~cm}^{-3}\right)$, то для достижения высоких уровней легирования применяются неравновесные методы введение примесей. К таковым относятся ионная имплантация или вакуумное осаждение пленок в сочетании с последующей импульсной лазерной обработкой в жидкофазном режиме, при которой достигаются повышенные уровни внедрения примеси в узельные (электроактивные) положения в решетке кремния и пониженный уровень дефектности.

В данном обзорном докладе приведены примеры из литературы по гипердопированию кремния халькогенидами и переходными металлами, при которых происходят вышеуказанные эффекты. Также продемонстрированы собственные результаты авторов работы по внедрению примесей железа и титана в кремний с использованием оригинальной методики распыления металлических мишеней низкоэнергетичным пучком ионов ксенона с одновременным внедрением распыленных атомов в кремний тем же ионным пучком без последующего термического отжига. При этом в тонком приповерхностном слое кремния (менее 10 нм) достигаются высокие уровни внедрения металлических примесей (свыше $10^{21} \mathrm{~cm}^{-3}$ ), инверсия типа проводимости, ферромагнетизм (для примеси железа), и интенсивный фотоотклик, превышающий таковой для типовых кремниевых фотодиодов.

Работа выполнена при финансовой поддержке РФФИ и Правительства Республики Татарстан в рамках научного проекта № 18-48-160011.

\section{Лumepamypa}

[1] W. Yang et al // Mater. Sci. Semicond. Proc. 2017. V.62. P.103-114.

[2] J.P. Mailoa et al. // Nat. Commun. 2014. V.5. P.3011(1-8).

[3] M. Wang et al. // Phys. Rev. Appl. 2018. V.10. P.024054(1-9).

[4] Y. Berencen et al. // Sci. Rep. 2017. V.7. P.43688(1-9). 